\title{
SISTEM PAKAR DENGAN ALGORITMA NAIVE BAYES UNTUK PREDIKSI HASIL PRODUKSI AYAM BROILER PLASMA (STUDI KASUS : PT.SEKAWAN SINAR SURYA)
}

\author{
Dudih Gustian $^{1 *}$, Indah Suciati ${ }^{2)}$, Sudin Saepudin ${ }^{3)}$ \\ ${ }^{1,2,3)}$ Program Studi Sistem Informasi, Universitas Nusa Putra Sukabumi, Indonesia \\ Jl. Raya Cibolang Kaler No.21, Sukabumi 43155 \\ e-mail: indahsuciati02@gmail.com ${ }^{1)}$,dudih@ @usaputra.ac.id ${ }^{2)}$, sudin@ @usaputra.ac.id $^{3)}$ \\ * Korespondensi: e-mail: dudih@nusaputra.ac.id
}

\begin{abstract}
ABSTRAK
Penelitian ini memberikan kontribusi kepada peternak atau pihak perusahaan dengan memberikan parameter yang berpengaruh untuk menentukan hasil produksi. Penggunaan algoritma Naive Bayes mampu menghasilkan prediksi klasifikasi keuntungan dan kerugian sebelum perhitungan realisasi pada bagian produksi. Untuk mengetahui nilai keakuratan pengujian dilakukan dengan menggunakan Software Weka. Akurasi rata-rata dari algoritma yang dihasilkan, Naive Bayes dari 96.36\% mendekati angka 100\% menunjukkan hasil yang maksimal. dan dengan nilai Receiver Operating Curve (ROC) 0,9995 mendekati angka 1 maka model yang dihasilkan lebih baik. Jadi dapat disimpulkan bahwa algoritma Naive Bayes adalah algoritma klasifikasi yang direkomendasikan untuk melakukan prediksi klasifikasi.
\end{abstract}

Kata Kunci: Peternak, Naive Bayes, Receiver Operating Curve

\begin{abstract}
This research contributes to a breeder or company parties by providing influential parameters to determine the results of production. The use of Naive Bayes algorithm is able to generate a profit and loss classification prediction prior to the calculation of the realisation on the part of production. To find out the value of the accuracy of the testing is done using Software Weka. The average accuracy of the resulting algorithm, Naive Bayes of $96.36 \%$ approaching $100 \%$ number indicates the maximum results. And with the value of the Receiver Operating Curve (ROC) 0.9995 approached the number 1 then the resulting model the better. So it can be inferred that the Naive Bayes algorithm is a classification algorithm that is recommended to do prediction of classification.
\end{abstract}

Keywords : Breeder, Naive Bayes, Receiver Operating Curve

\section{PENDAHULUAN}

\subsection{Latar Belakang}

Ayam broiler adalah salah satu jenis ayam pedaging ras unggul yang dipelihara untuk dimanfaatkan dagingnya. Ayam tersebut dihasilkan melalui perkawinan silang, seleksi dan rekayasa genetik yang dilakukan oleh pembibitnya. Broiler merupakan jenis ras unggulan hasil persilangan dari bangsa-bangsa ayam yang memiliki produktivitas tinggi, terutama dalam memproduksi daging [1].

Menjalankan usaha dalam bidang peternakan ayam broiler mempunyai prospek yang cukup bagus. Hal ini dikarenakan selain merupakan ternak unggas dengan masa pemeliharaan yang relatif singkat antara 56 minggu, juga keuntungan yang menjanjikan. Dimana konsumsi ayam broiler atau sering disebut ayam potong yang semakin tinggi atas kesadaran masyarakat bahwa ayam merupakan sumber protein hewani dengan harga jual yang terbilang relatif murah.

PT. Sekawan Sinar Surya merupakan perusahaan yang bergerak di bidang industri budidaya broiler dan kemitraan berlokasi di Komplek IPB 2 JL. Vesta Blok M No.12 Desa Ciherang Kecamatan Dramaga Kabupaten Bogor. Mempunyai beberapa kerjasama kemitraan dengan plasma yang berada di Sukabumi, 
Bogor, Cikampek dan Serang. Keberhasilan para peternak dalam mengelola pemeliharaan ayam hingga mendapatkan keuntungan adalah tidak terlepas dari manajemen yang diterapkan. Manajemen yang baik akan menemukan masalah lebih dini dan menemukan solusi lebih cepat sehingga dalam mengelola peternakan akan lebih optimal. Oleh karena itu dibutuhkan evaluasi untuk masa pemeliharaan hingga keputusan hendak dipanen. Bagi peternak yang sudah cukup lama menggeluti bidang ini tentunya tidak kesulitan dalam memprediksi hasil akhir produksi setiap periodenya. Lain halnya bagi peternak pemula kesulitan dalam menentukan kapan waktu panen yang tepat untuk menghasilkan keuntungan maupun meminimalisir kerugian. Adapun permasalahan pada PT.Sekawan Sinar Surya dimana masih banyak peternak yang belum mandiri untuk memonitoring sendiri produksinya. Sehingga peternak sering mengalami kerugian setiap periodenya. Peternak masih mengandalkan Technical Support (TS) dari perusahaan untuk langsung memantau ditempat. Namun karena satu orang TS memegang tanggung jawab kepada beberapa peternak sehingga diupayakan agar peternak mampu melakukan prediksi hasil produksinya sendiri apakah untung atau rugi.

Pada penelitian ini akan digunakan metode Naive Bayes dalam penyelesaian masalah prediksi hasil produksi. Sebagai referensi metode Naive Bayes dipilih pada penelitian sistem pakar untuk mendiagnosa penyakit ayam broiler dan peterlur. Dimana metode ini dikembangkan untuk membantu pengguna khususnya peternak dalam mendiagnosis penyakit yang menghasilkan nilai probabilitas tiap-tiap penyakit, kemudian mengambil nilai yang terbesar. Tingkat akurasi hasil diagnosa mencapai $80 \%$ sehingga metode ini cukup disarankan dalam kasus tersebut [2]. Sementara melihat dari penelitian analisis teknik data mining algoritma $\mathrm{C} 4.5$ dan K-nearest neighbors untuk mendiagnosa penyakit diabetes mellitus. Hasil perbandingan menunjukkan bahwa algoritma C4.5 menghasilkan tingkat akurasi sebesar 76,105\% dan algoritma K-nearest neighbors sebesar 79,1436\% [3]. Melihat dari kedua penelitian tersebut, sehingga penulis menggunakan metode Naive Bayes karena menghasilkan nilai akurasi tertinggi.

Penerapan metode ini diharapkan memberikan solusi dalam mengklasifikasikan hasil produksi ayam broiler berupa untung dan rugi pada plasma dengan cara menghitung nilai probabilitas masing-masing atribut. Dimana dengan pengklasifikasian tersebut dapat dihasilkan nilai probabilitas tertinggi yang kemudian dijadikan hasil prediksi. Penelitian ini memberikan kontribusi bagi peternak maupun pihak perusahaan dengan memberikan parameter yang berpengaruh untuk menentukan hasil produksi yang yang diharapkan. Sehingga diharapkan dapat menjadi pertimbangan peternak dan perusahaan agar segera menentukan waktu panen apabila hasil prediksi menghasilkan klasifikasi rugi.

\section{TINJAUAN PUSTAKA}

\subsection{Penelitian Terkait}

Moh.Wahyul Hadi Saputro dari Universitas Muhamadiyah Gresik (2017) dengan judul "Sistem Untung Rugi Pada Hasil Peternakan Ayam Broiler Dengan Metode Klasifikasi Naive Bayes". Penelitian ini menerapkan data mining teknik klasifikasi dengan menggunakan metode Naïve Bayes untuk menentukan untung dan rugi peternakan ayam broiler. Dataset yang digunakan adalah data peternakan ayam broiler di CV. Mitra Wijaya Mulya dengan parameter terdiri dari 5 variabel yaitu : musim, populasi, strain (bibit), Ovk (obat), dan feed (pakan). Pengujian sistem dilakukan sebanyak tiga kali pengujian yang masingmasing pengujian diulang sebanyak dua kali dengan komposisi data latih yang berbeda-beda. Dari semua hasil penelitian akurasi tertinggi terdapat pada pengujian pertama yaitu dengan nilai prediksi 71,24\% [4].

Oktariani Nurul Pratiwi dari Universitas Widyatama Bandung (2016), dengan judul "Analisa Perbandingan Algoritma K-Means, Decision Tree dan Naive Bayes Untuk Sistem Pengelompokkan Siswa Otomatis". Penelitian ini bertujuan untuk menentukan kelompok belajar secara otomatis dengan menerapkan algoritma data mining. Dalam penelitian ini menggunakan 3 algoritma yaitu K-Means, Decision Tree dan Naive Bayes. Dataset yang dipakai dari data Siswa SMPN 2 Bandung Kelas VIII-I, VIII-J, VIIIK tahun ajaran 2014 / 2015 dan menggunakaan parameter 6 variabel yaitu : tempat, pendidikan, menyukai, motivasi, teman dekat dan learning. Selanjutnya ketiga algoritma tersebut dibandingkan untuk mendapatkan nilai akurasi terbaik. Dan hasilnya menunjukkan bahwa algoritma Naive Bayes mempunyai nilai akurasi tertinggi sebesar 70,37\% [5]. 
Valentinus Roby Hananto dari Stikom Surabaya (2017), dengan judul “Analisis Penentuan Metode Data Mining Untuk Prediksi Kelulusan Mahasiswa Sebagai Penunjang Angka Efisiensi Edukasi”. Tujuan dari penelitian ini bagaimana melakukan prediksi kelulusan mahasiswa sebagai penunjang pengambilan keputusan dalam upaya meningkatkan AEE (Angka Efisiensi Edukasi) menggunakan data mining klasifikasi dan membandingkannya untuk mengetahui metode dengan nilai akurasi tertinggi. Dataset diambil dari data akademik mahasiswa Sistem Informasi semester 15.2 dengan parameter nim, nama, dosen wali, IPK, SKSK, STS, STS_Tempuh_KP, dosen 1, dosen 2 dan lulus tepat waktu. Metode klasifikasi yang dipakai seperti : Naive Bayes, Multi Layer Perceptron, SMO, J48 dan REPTree menghasilkan metode dengan akurasi tertinggi dan error rate terkecil adalah Naive Bayes dengan tingkat akurasi sebesar 57,3\% [6].

Noora Abdulrahman and Wala Abedalkhader dari Masdar Institute of Science and Technology (2017) dengan judul "KNN Classifier and Naive Bayes Classifier For Crime Prediction in San Fransisco Context". Penelitian ini bertujuan untuk prediksi kejahatan yang terjadi di San Fransisco dengan menggunakan dua metode klasifikasi yaitu : KNN dan Naive Bayes. Dataset diambil dari SFPD Crime Incident Reporting system dari bulan Januari 2003 sampai Mei 2015 dengan parameter : tanggal, kategori, deskripsi, minggu ke, nama departemen kepolisian, bagaimana kejadian tersebut diselesaikan, alamat, $x$ (longitude), dan y (latitude). Hasil dari penelitian ini menunjukkan bahwa tingkat akurasi tertinggi terdapat pada metode Naive Bayes menggunakan pengujian cross validation [7].

\subsection{Ayam Broiler}

Ayam pedaging adalah ayam jantan dan betina muda yang berumur di bawah 8 minggu dan ketika dijual memiliki bobot tubuh tertentu, mempunyai pertumbuhan yang cepat, serta mempunyai dada yang lebar dengan timbunan daging yang baik dan banyak [8].

Data dari Direktorat Jenderal Peternakan dan Kesehatan Hewan, Kementerian Pertanian Republik Indonesia menunjukkan perkisaran populasi ayam pedaging di Indonesia selama 5 tahun secara nasional berturut-turut 892 juta ekor (2007), 902 juta ekor (2008), 1 milyar ekor (2011). Meski demikian, jumlah tersebut masih belum menutupi permintaan pasar daging asal unggas. Karena itu, peluang usaha beternak ayam broiler masih sangat menjanjikan [9].

Potensi genetik akan muncul apabila didukung oleh faktor lingkungan yang sesuai dengan kondisi tumbuh kembang ayam broiler tersebut. Faktor lingkungan yang paling berpengaruh terhadap prestasi produksi daging ayam broiler diantaranya temperatur, pakan, air, tingkat kepadatan dan udara [10].

\subsection{Manajemen Pemeliharaan}

Peternak yang menginginkan keberhasilan dalam usaha peternakan broiler mau tidak mau harus memiliki manajemen yang baik.

\subsection{Sistem Pakar}

Dengan kata lain, sistem pakar adalah sistem komputer yang ditujukan untuk meniru semua aspek kemampuan pengambilan keputusan (decision making) seorang pakar. Sistem pakar memanfaatkan secara maksimal pengetahuan khusus selayaknya seorang pakar untuk memecahkan masalah. Sedangkan pakar atau ahli (expert) didefinisikan sebagai seorang yang memiliki pengetahuan atau keahlian khusus yang tidak dimiliki oleh kebanyakan orang. Dengan kata lain, dapat memecahkan suatu masalah dengan lebih efisien [11].

\subsection{Data Mining}

Data mining adalah suatu istilah yang digunakan untuk menguraikan penemuan pengetahuan di dalam database. Data mining adalah proses yang menggunakan teknik statistik, matematika, kecerdasan buatan dan machine learning untuk mengekstraksi dan mengidentifikasi informasi yang bermanfaat dan pengetahuan yang terakit dari berbagai proses besar. Menurut Gartner Group, Data Mining sebagai suatu proses menemukan hubungan yang berarti, pola, dan kecenderungan dengan memeriksa dalam sekumpulan besar data yang tersimpan dalam penyimpanan dengan menggunakan teknik pengenalan pola seperti teknik statisik dan matematika [12]. 
Diagram bidang ilmu data mining dapat dilihat dari gambar dibawah ini [13] :

1. Proses Data Mining

Pada proses Data Mining yang biasa disebut Knowledge Discovery Database (KDD) terdapat beberapa proses seperti terlihat pada gambar di bawah ini:

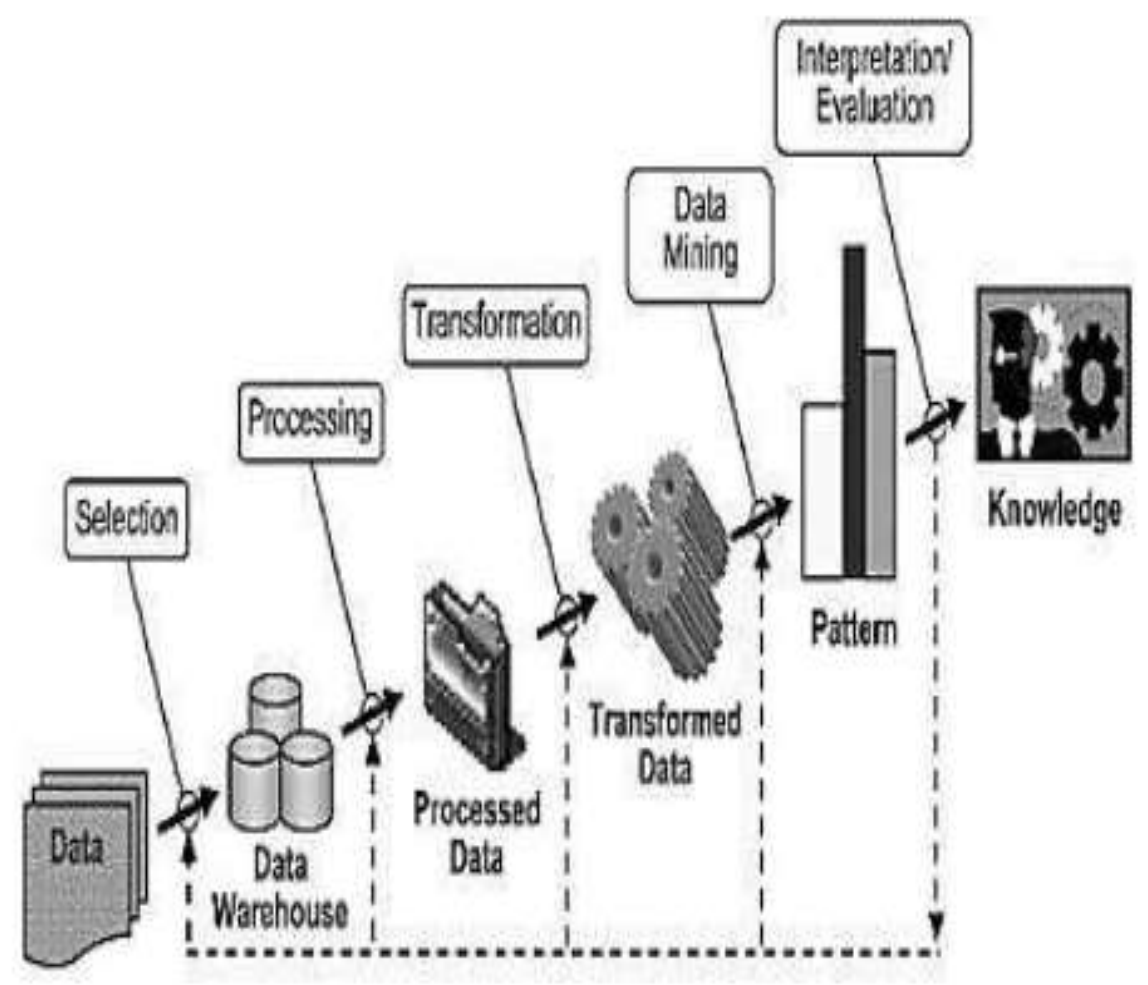

Gambar 1. Knowledge Discovery Database (KDD)

\section{Metode Klasifikasi}

Klasifikasi merupakan sebuah proses training (pembelajaran) suatu fungsi tujuan (target) yang digunakan untuk memetakan tiap himpunan atribut suatu objek kesatu dari label kelas tertentu yang didefinisikan sebelumnya. Teknik Klasifikasi ini cocok digunakan dialam mendeskripsikan dataset dengan tipe data dari suatu himpunan data yaitu biner atau nominal. Ada beberapa teknik klasifikasi yang digunakan sebagai solusi pemecahan kasus diantaranya Algoritma C4.5, Algoritma K-Nearest Neighbor, ID3, Nä̈ve Bayesian Classification, CART (Classification And Regression Tree) dan lain-lain.

3. Naive Bayes

Nä̈ve Bayesian Classifier merupakan salah satu algoritma pemecahan masalah yang termasuk kedalam Metode Klasifikasi pada Data Mining. Nä̈ve Bayesian Classifier mengadopsi ilmu statistika yaitu dengan menggunakan teori kemungkinan (probabilitas) untuk menyelesaikan sebuah kasus supervised learning, artinya dalam himpunan data terdapat label, class atau target sebagai acuan atau gurunya.

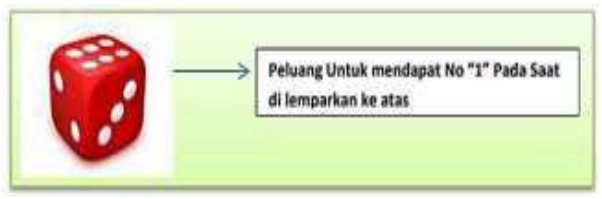

Gambar 2. Ilustrasi Peluang

Dari gambar di atas dapat kita mengetahui secara sederhana bahwasanya peluang untuk mendapatkan no.1 yaitu : 1/6. Dengan asumsi jumlah yang bernilai dadu no.1 ada 1 sedangkan total keseluruhan dadu ada 6. Berikut ini adalah rumus untuk mencari nilai peluang dari Hipotesa benar (valid) untuk data sampel $\mathrm{X}$ yaitu : 


$$
\mathrm{P}(\mathrm{H} \mid \mathrm{X})=\frac{\mathrm{P}(\mathrm{X} \mid \mathrm{H}) \cdot \mathrm{P}(\mathrm{H})}{\mathrm{P}(\mathrm{X})}
$$

Dari rumus di atas, sebagai dasar teori bayesian sebagai pemecahan masalah, kita harus mengetahui terlebih dahulu beberapa hal diantaranya yaitu :

$\mathrm{X} \quad$ : sampel data yang memiliki kelas (label) yang tidak diketahui

$\mathrm{H} \quad$ : hipotesa bahwa $\mathrm{x}$ adalah data kelas (label)

$\mathrm{P}(\mathrm{H})$ : peluang dari hipotesa

$\mathrm{H} P(\mathrm{X})$ : peluang dari data sampel yang diamati

$\mathrm{P}(\mathrm{X} \mid \mathrm{H})$ : peluang dari data sampel $\mathrm{X}$ bila diasumsikan bahwa hipotesa benar

\subsection{Kerangka Pemikiran}

Berikut kerangka pemikiran yang diterapkan pada penelitian ini :

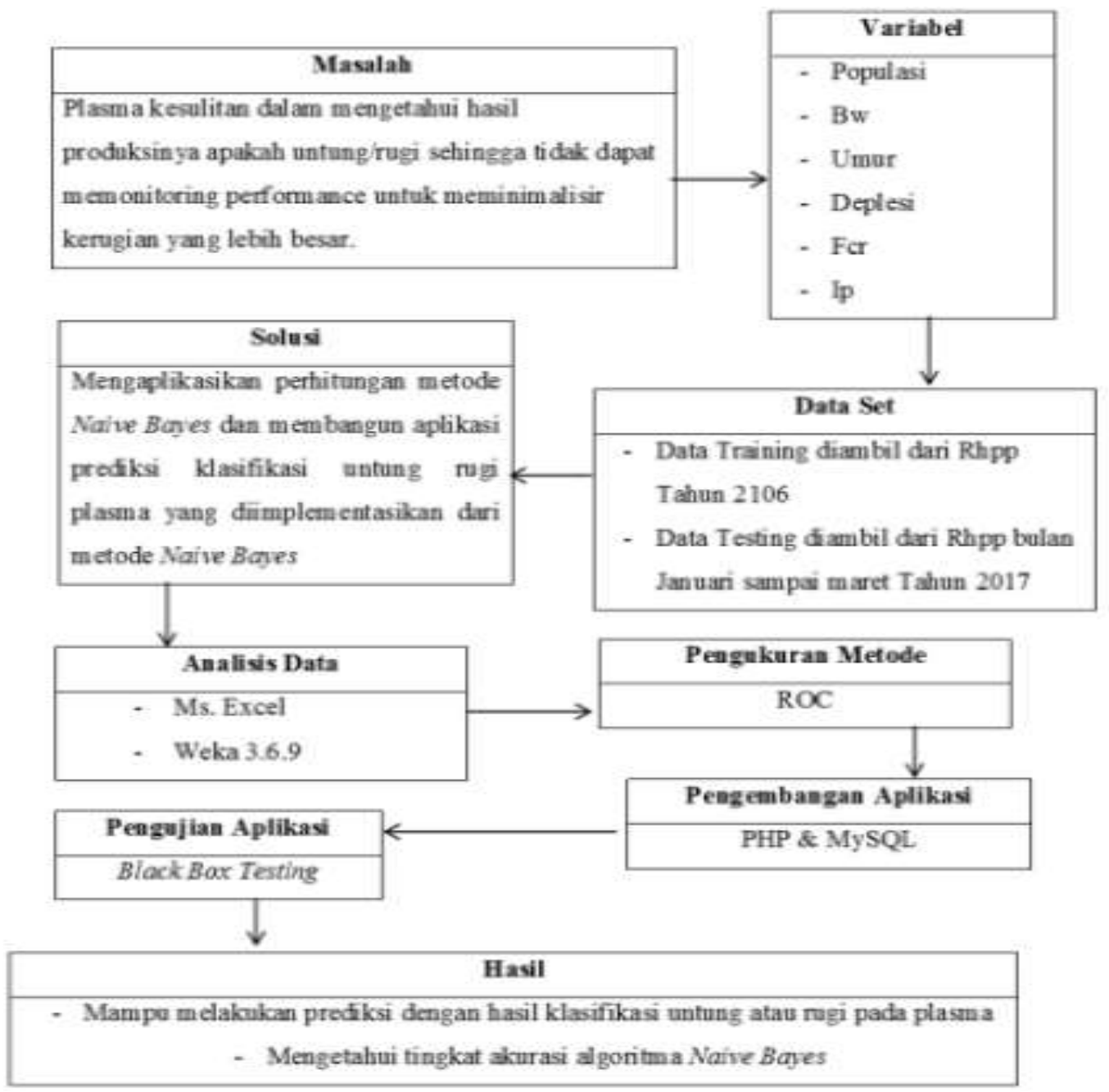

Gambar 3. Kerangka Pemikiran

\section{METODOLOGI PENELITIAN}

\subsection{Tahapan Penelitian}

1. Pengumpulan Data

Pada tahap ini dilakukan pengumpulan data tentang teori-teori algoritma Naive Bayes, data asli RHPP PT.Sekawan Sinar Surya, cara menghitung klasifikasi menggunakan algoritma Naive Bayes dan software apa yang dapat digunakan untuk membantu menghasilkan nilai persentase akurasi algoritma tersebut. Semua proses pengumpulan data diperoleh dari observasi dan studi pustaka. 
2. Pengolahan Data

Sebelum data diolah, dilakukan pemrosesan data terlebih dahulu sesuai dengan proses KDD.

a. Seleksi Data. Pada tahap in dilakukan penyeleksian data untuk mengurangi data yang tidak relevan dan redundant (atribut yang berlebihan). Pada data RHPP berisi 18 atribut, dan tidak semua dipakai untuk mengklasifikasi prediksi untung rugi plasma.

b. Transformasi Data. Pada tahap ini yang dilakukan adalah mentransformasi bentuk data yang belum memiliki entitas yang jelas kedalam bentuk data yang valid atau siap untuk dilakukan proses data mining.

c. Data Mining. Pada tahap ini yang dilakukan adalah melakukan perhitungan data mining menggunakan algoritma yang dipakai yaitu Naive Bayes untuk menghasilkan nilai akurasi data.

d. Interpretasi. Pada tahap terakhir ini dilakukan proses pembentukan keluaran prediksi berupa klasifikasi untung dan rugi plasma.

3. Perancangan Algoritma

Tahapan perancangan menggunakan algoritma Naive Bayes :

a. Menetukan data plasma.

b. Pengelompokan atribut bertujuan untuk mempermudah perhitungan probabilitas dalam proses prediksi untung rugi plasma.

c. Menghitung probabilitas nilai yang ingin dibandingkan.

d. Menghitung probabilitas populasi, bw, deplesi, fcr, umur dan ip.

e. Menghitung probabilitas data latih dengan mengalikan seluruh probabilitas kelas data latih dengan probabilitas data uji untuk mendapatkan nilai probabilitas akhir.

f. Bandingkan probabilitas akhir untung dan rugi, pilih probabilitas yang paling tinggi nilainya.

g. Selesai

\subsection{Data Penelitian}

\section{HASIL PENELITIAN}

Penelitian ini dibagi menjadi dua bagian, yaitu data training sebanyak 289 sampel dan data testing sebanyak 53 data. Dimana data training diambil dari RHPP periode bulan Januari sampai Desember Tahun 2016. Sedangkan data testing diambil dari RHPP periode bulan Januari sampai Maret tahun 2017. Data training dan data testing yang sudah dikelompokkan kemudian akan dilakukan proses data mining menggunakan software Weka 3.6.9.

\subsection{Pengelompokkan Data}

Dalam hal ini penulis hendak menganalisa data yang telah dijelaskan sebelumnya berdasarkan parameter yang berpengaruh untuk selanjutnya digunakan sebagai data training dalam memprediksi untung rugi plasma menggunakan metode klasifikasi Naive Bayes.

\subsection{Pengujian}

1. Visualisasi Performa Receiver Operating Characteristic (ROC)

Kurva ROC adalah salah satu teknik yang dapat memvisualisasikan, mengorganisasi, dan memilih classifier berdasarkan performanya. ROC merupakan hasil dari pengukuran klasifikasi dalam bentuk 2 dimensi dimana garis horisontal menggambarkan nilai false positive dan garis vertikal sebagai true positive.

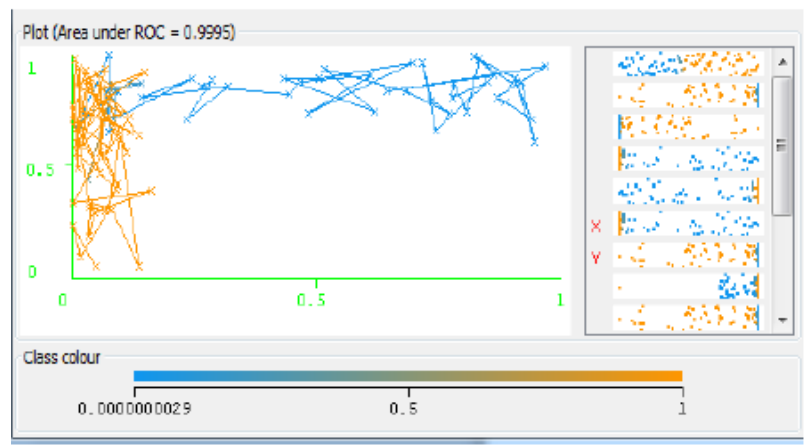

Gambar 4. Kurva ROC Target Kelas Untung 
Gambar diatas menunjukkan visualisasi performa algoritma Naive Bayes dengan ROC menampilkan nilai Area Under ROC pada kelas untung sebesar 0,9995 dengan menunjukkan warna biru sebagai kelas True dan warna orange sebagai kelas false.

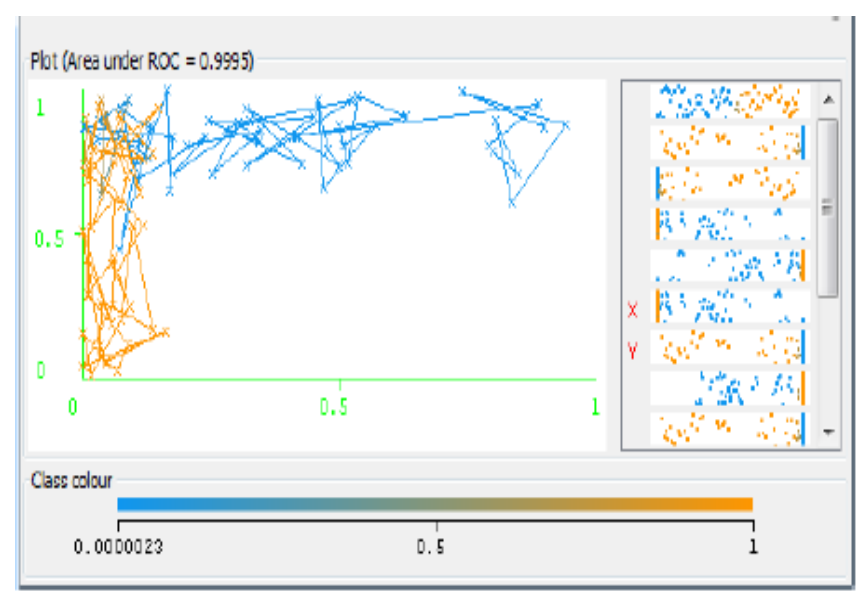

Gambar 5. Kurva ROC Target Kelas Rugi

Gambar diatas menunjukkan visualisasi performa algoritma Naive Bayes dengan ROC menampilkan nilai Area Under ROC pada kelas rugi sebesar 0,9995 dengan menunjukkan warna biru sebagai kelas True dan warna orange sebagai kelas false.

2. Pengujian Use Training Test

Pengujian use training set ini mengambil data pelatihan dan data uji yang sama. Dan hasil pengujian menggunakan mode Use training set dapat dilihat pada tabel berikut :

Tabel 1. Hasil Pengujian Use Training Set

\begin{tabular}{|l|l|l|l|}
\hline No & Prediksi Benar & Prediksi Salah & Akurasi (\%) \\
\hline 1 & 279 & 10 & $96,54 \%$ \\
\hline
\end{tabular}

Dari tabel diatas dapat dilihat bahwa pengujian menggunakan mode use training set menghasilkan nilai akurasi yang cukup baik yaitu $96,54 \%$.

3. Pengujian Suplied Test Set

Mode pengujian ini menggunakan data testing yang diambil dari data bulan Januari sampai Maret tahun 2017 yaitu bulan januari sebanyak 22 data, bulan februari sebanyak 18 data, dan bulan maret sebanyak 13 data.

Tabel 2. Hasil Suplied Test Set Bulan Januari

\begin{tabular}{|c|c|c|c|c|c|c|c|c|}
\hline \multicolumn{9}{|c|}{ prediksi-januari,arff } \\
\hline \multicolumn{9}{|c|}{ Relation: untung rug predicted } \\
\hline No. & $\begin{array}{l}\text { populasi } \\
\text { Neminal }\end{array}$ & $\begin{array}{l}\text { bw } \\
\text { Nominal }\end{array}$ & $\begin{array}{l}\text { deplesi } \\
\text { Nominal }\end{array}$ & $\begin{array}{l}f a r \\
\text { Nominal }\end{array}$ & $\begin{array}{l}\text { umur } \\
\text { Nominal }\end{array}$ & Nominai & $\begin{array}{c}\text { predicteddass } \\
\text { Nominal }\end{array}$ & $\underset{\text { Nominat }}{\text { Class }}$ \\
\hline 1 & $5001-10000$ & $1,56-2,00$ & $5,01-10,00$ & $1,400-1,700$ & 27.32 & 301.350 & untung & untung \\
\hline 2 & $1000-5000$ & $1,56-2,00$ & $5,01-10,00$ & $1,400-1,700$ & $27 \cdot 32$ & $301-350$ & untung & untung \\
\hline 3 & $1000-5000$ & $1,56 \cdot 2,00$ & $15,01 \cdot 30,00$ & $1,400-1,700$ & $27 \cdot 32$ & $251 \cdot 300$ & untung & untung \\
\hline 4 & $1000 \cdot 5000$ & $1,56-2,00$ & $15,01-30,00$ & $1,400-1,700$ & 93.40 & $251 \cdot 300$ & untung & untung \\
\hline 5 & $1000-5000$ & $1,56 \cdot 2,00$ & $10,01-15,00$ & $1,701-2,000$ & $33 \cdot 40$ & $251 \cdot 300$ & untung & untung \\
\hline 6 & $1000=000$ & $1,562 \% 00$ & $1,0,0150,00$ & $1.01 .2,000$ & $3 y-40$ & 0.250 & Tual & unturg \\
\hline 7 & $10001-15000$ & $1,56-2,00$ & $0-5,00$ & $1,400-1,700$ & $27 \cdot 32$ & 301.350 & untung & untung \\
\hline a & $1000 \cdot 5000$ & $1,56-2,00$ & $5,01-10,00$ & $1,400-1,700$ & $33 \cdot 40$ & $301-350$ & untung & untung \\
\hline 9 & $1000-5000$ & $1,56-2,00$ & $5,01-10,00$ & $1,400-1,700$ & 27.32 & 301.350 & untung & untung \\
\hline 10 & $1000-5000$ & $1,56-2,00$ & $5,01-10,00$ & $1,400-1,700$ & $33-40$ & $251-300$ & untung & untung \\
\hline 11 & $5001-10000$ & $1,56-2,00$ & $5,01-10,00$ & $1,400-1,700$ & $27-32$ & 301.350 & untung & untung \\
\hline 12 & $1000-5000$ & $1,56 \cdot 2,00$ & $5,01-10,00$ & $1,701 \cdot 2,000$ & $27 \cdot 32$ & 301.350 & untung & untung \\
\hline 13 & $1000-5000$ & $1,56-2,00$ & $0-5,00$ & $1,400-1,700$ & $27-32$ & $301-350$ & untung & untung \\
\hline 14 & $1000-5000$ & $1,56-2,00$ & $0.5,00$ & $1,400-1,700$ & $33-40$ & 301.350 & untung & untung \\
\hline 15 & $1000-5000$ & $1,56-2,00$ & $5,01-10,00$ & $1,701-2,000$ & $33-40$ & 251.300 & untung & untung \\
\hline 76 & 5001010000 & 1506.165 & $5.01-10,00$ & 1.7015000 & 2732 & 151800 & untung & rugr \\
\hline 17 & $10001-15000$ & $1,56 \cdot 2,00$ & $5,01-10,00$ & $1,400-1,700$ & $39 \cdot 40$ & 251.300 & untung & untung \\
\hline is & $1000-5000$ & $1,06-1,55$ & $5,01-10,00$ & $1,400-1,700$ & $27 \cdot 32$ & $251-300$ & untung & untung \\
\hline 19 & 10001.15000 & $1,56 \cdot 2,00$ & $0.5,00$ & $1,400 \cdot 1,700$ & 27.32 & $301 \cdot 350$ & untung & untung \\
\hline 20 & $1000-5000$ & $1,56-2,00$ & $5,01 \cdot 10,00$ & $1,400-1,700$ & $33-40$ & 301.350 & untung & untung \\
\hline 21 & $5001-10000$ & $1,06-1,55$ & $10,01-15,00$ & $1,701-2,000$ & 27.32 & $0-250$ & rugi & rugi \\
\hline 22 & $1000-5000$ & $1,06-1,55$ & $5,01-10,00$ & $1,400-1,700$ & 27.32 & 251.300 & untung & untung \\
\hline
\end{tabular}

Hasil analisis yang diperoleh dari pengujian yang ditampilkan bahwa pada data 6 seharusnya menampilkan hasil untung dan pada data 16 seharusnya menampilkan hasil rugi. 
Tabel 3. Hasil Suplied Test Set Bulan Februari

\begin{tabular}{|c|c|c|c|c|c|c|c|c|}
\hline \multicolumn{9}{|c|}{ prediksi-feb arff } \\
\hline \multicolumn{9}{|c|}{ Relation untung-ugi predicted } \\
\hline No & $\begin{array}{l}\text { popitasi } \\
\text { Nominal }\end{array}$ & $\begin{array}{c}\text { bw } \\
\text { Nominal }\end{array}$ & $\begin{array}{l}\text { deplesi } \\
\text { Nominal }\end{array}$ & $\begin{array}{c}\text { for } \\
\text { Nominal }\end{array}$ & \begin{tabular}{|c} 
umuir \\
Noninal
\end{tabular} & $\begin{array}{c}\text { is } \\
\text { Nominal }\end{array}$ & $\begin{array}{c}\text { predicteddass } \\
\text { Nominal }\end{array}$ & $\begin{array}{c}\text { dass } \\
\text { Nemina }\end{array}$ \\
\hline 1 & $1000-5000$ & $1,56 \cdot 2,00$ & $5,01 \cdot 10,00$ & $1,400 \cdot 1,700$ & $27-32$ & 301.350 & untung & untung \\
\hline 2 & $1000-6000$ & 1,562200 & $15,5020,00$ & $10,012,000$ & 2732 & 0250 & +00 & Malues. \\
\hline 3 & $1000-5000$ & $1,56 \cdot 2,00$ & $15,01 \cdot 30,00$ & $1,701 \cdot 2,000$ & $39-40$ & 0.250 & rug & hugi \\
\hline 4 & $1000-5000$ & $1,56 \cdot 2,00$ & $5,01 \div 10,00$ & $1,400-1,700$ & $33-40$ & $301-350$ & untung & untung \\
\hline 5 & $1000-5000$ & $1,56 \cdot 2,00$ & $5,01 \cdot 10,00$ & $1,400-1,700$ & $27 \cdot 12$ & 301,350 & untung & untung \\
\hline 6 & 10505000 & $1,06 \cdot 1,55$ & $5,01 \cdot 10,00$ & $1,400-1,700$ & 2732 & 251,300 & untung & untung \\
\hline 7 & $1000-5000$ & $1,06-1,55$ & $0-5,00$ & $1,400-1,700$ & $27-32$ & 301.350 & untung & untung \\
\hline 8 & $1000-5000$ & $1,56 \cdot 2,00$ & $5,01-10,00$ & $1,400-1,700$ & $27-32$ & $251 \cdot 300$ & untung & untung \\
\hline 9 & $1000-5000$ & $1,06 \cdot 1,55$ & $10,01 \cdot 15,00$ & $1,701-2,000$ & 27.92 & $0-250$ & rug & pugi \\
\hline 10 & $1000-5000$ & $1,06 \cdot 1,55$ & $0.5,00$ & $1,400-1,700$ & $27-32$ & $251 \cdot 300$ & untung & untung \\
\hline 11 & $1000-5000$ & $1,56 \cdot 2,00$ & $0.5,00$ & $1,400-1,700$ & $27-32$ & $301-350$ & untung & untung \\
\hline 12 & $1000-5000$ & $1,56 \cdot 2,00$ & $5,01 \cdot 10,00$ & $1,701 \cdot 2,000$ & $27 \cdot 32$ & $251 \cdot 300$ & untung & untung \\
\hline 13 & $1000-5000$ & $1,56 \cdot 2,00$ & $5,01-10,00$ & $1,400-1,700$ & $27-32$ & $301-350$ & untung & unteng \\
\hline 14 & $5001-10000$ & $1,56 \cdot 2,00$ & $5,01-10,00$ & $1,400-1,700$ & $27-32$ & 301.350 & untung & unting \\
\hline 15 & $1000-5000$ & $1,56 \cdot 2,00$ & $0.5,00$ & $1,400-1,700$ & $39-4)$ & $301-350$ & untung & untung \\
\hline 16 & $5001+10000$ & $1,06+1,58$ & $5,01 \cdot 10,00$ & $2,001 \cdot 3,000$ & 39.40 & 0.250 & rug & fugi \\
\hline 17 & $10001 \cdot 15000$ & $1,56 \cdot 2,00$ & $0.5,00$ & $1,400-1,700$ & 33.40 & 301.350 & untung & untung \\
\hline 18 & $15001-30000$ & $1,56 \cdot 2,00$ & $0.5,00$ & $1,400-1,700$ & $33 \cdot 40$ & 301.350 & untung & untune \\
\hline
\end{tabular}

Hasil analisis yang diperoleh dari pengujian yang ditampilkan pada gambar diatas bahwa terdapat prediksi yang kurang tepat pada data 2 seharusnya menampilkan hasil untung.

Tabel 4. Hasil Suplied Test Set Bulan Maret

\begin{tabular}{|c|c|c|c|c|c|c|c|c|}
\hline & 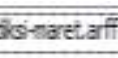 & & & & & & & \\
\hline & & & & & & & & \\
\hline hic. & $\begin{array}{l}\text { populasi } \\
\text { locriral }\end{array}$ & bar & $\begin{array}{l}\text { deples } \\
\text { Noninal }\end{array}$ & $\begin{array}{l}\text { fo } \\
\text { Moniral }\end{array}$ & \begin{tabular}{|l} 
umes \\
Nonira
\end{tabular} & Norira & $\begin{array}{c}\text { predictedtass } \\
\text { Norind }\end{array}$ & $\begin{array}{l}\text { dass } \\
\text { Nomina }\end{array}$ \\
\hline I & $1000-5000$ & $1,30-2,00$ & $5,01-10,00$ & $1,001-2,000$ & $12-4$ & $251-300$ & untung & Untung \\
\hline 2 & $1000-5600$ & $1,56-2,00$ & $5,01-10,00$ & $1,408-1,700$ & $13-4$ & $251-300$ & untung & unting \\
\hline 3 & 1200-5ion & $1,56-2,00$ & $5,01-10,00$ & $1,701-2,000$ & $77-32$ & $251-300$ & untung & untung \\
\hline 4 & $1000-5600$ & $106-1,55$ & $5,01-10,00$ & $1,701-2,000$ & $77-32$ & $10-251$ & nog & gوس \\
\hline 5 & $1000-5000$ & $106-1,55$ & $5,01-10,00$ & $1,701-2,000$ & $77-32$ & $251-300$ & untung & untung \\
\hline 5 & $5001-10000$ & $1,56-2,00$ & $0-5,00$ & $1,490-1,700$ & $13-4$ & $301-350$ & unturg & untung \\
\hline 7 & $1000-5600$ & $156-2,00$ & $0-5,00$ & $1,490-1,700$ & $77-32$ & $301-350$ & unturo & untung \\
\hline 8 & 5001-12000 & $106-1,55$ & $0,01-15,00$ & $2,001-3,000$ & $17-32$ & $0-250$ & nog & rug \\
\hline 9 & $1022-5000$ & $106-1,55$ & $0,01-15,00$ & $2,001-3,000$ & $27-32$ & $0-250$ & $n g$ & gin \\
\hline 18 & $1002-5000$ & 7.,55-1,05 & $5,01-10,00$ & $2,001-3,000$ & $27-32$ & 0.250 & $n g$ & gin \\
\hline II & $1002-5000$ & $106-1,55$ & $5,01-10,10$ & $1,001-2,000$ & $17-32$ & $0-250$ & ng & rug \\
\hline 12 & $1021-5006$ & $106-1,55$ & $0,01-15,00$ & $1,001-2,002$ & $33-40$ & $0-250$ & $n g$ & mig \\
\hline 13 & $1002-5000$ & $106-1,55$ & $5,01-10,10$ & $1,001-2,000$ & $27-32$ & 0.250 & rog & mog \\
\hline
\end{tabular}

Hasil analisis yang diperoleh dari pengujian yang ditampilkan pada gambar diatas bahwa tidak terdapat hasil prediksi yang kurang tepat artinya menghasilkan hasil prediksi yang maksimal.

Tabel 5. Hasil Pengujian Supplied Test Set

\begin{tabular}{cccc}
\hline $\begin{array}{c}\text { Data Testing } \\
\text { (bulan) }\end{array}$ & $\begin{array}{c}\text { Prediksi } \\
\text { Benar }\end{array}$ & $\begin{array}{c}\text { Prediksi } \\
\text { Salah }\end{array}$ & $\begin{array}{c}\text { Akurasi } \\
(\%)\end{array}$ \\
\hline Januari & 20 & 2 & 90,91 \\
Februari & 17 & 1 & 94,44 \\
Maret & 13 & 0 & 100 \\
\hline
\end{tabular}

Dari tabel diatas dapat dilihat bahwa pengujian mode supplied test set menghasilkan prediksi yang sempurna pada pengujian data bulan maret yaitu sebesar $100 \%$.

4. Pengujian Cross-Validation

Mode pengujian ini yaitu mengevaluasi algoritma melalui cross-validation, menggunakan nilai fols yang dimasukkan dengan data testing. Misal kita menentukan k=3 maka data dibagi 3 dan pengujian akan dilakukan sebanyak 3 kali dengan menggunakan data testing sebagai data pengujian, dan seterusnya.

Tabel 6. Hasil Pengujian Cross-Validation

\begin{tabular}{cccc}
\hline $\begin{array}{c}\text { Banyaknya } \\
\text { fold }\end{array}$ & $\begin{array}{c}\text { Prediksi } \\
\text { Benar }\end{array}$ & $\begin{array}{c}\text { Prediksi } \\
\text { Salah }\end{array}$ & $\begin{array}{c}\text { Akurasi } \\
(\%)\end{array}$ \\
\hline
\end{tabular}




$\begin{array}{cccc}3 & 280 & 9 & 96,89 \\ 6 & 280 & 9 & 96,89 \\ 10 & 279 & 10 & 96,54\end{array}$

Dari tabel diatas dapat dilihat bahwa pengujian mode cross validation menghasilkan akurasi tertinggi pada pengujian $\mathrm{k}=3$ dan $\mathrm{k}=6$ yaitu sebesar $96.54 \%$.

5. Pengujian Percentage Split

Pada mode pengujian ini data training sebanyak 289 data yang akan dibagi menjadi data pelatihan dan data uji sesuai dengan presentase yang ditentukan. Hasil dari pengujian mode ini menggunakan algoritma Naive Bayes adalah sebagai berikut :

Tabel 7. Hasil Pengujian Percentage Split

\begin{tabular}{cccc}
\hline $\begin{array}{c}\text { Percentage } \\
\text { Split }(\%)\end{array}$ & $\begin{array}{c}\text { Prediksi } \\
\text { Benar }\end{array}$ & $\begin{array}{c}\text { Prediksi } \\
\text { Salah }\end{array}$ & $\begin{array}{r}\text { Akurasi } \\
(\%)\end{array}$ \\
\hline $\mathbf{9 0}$ & 29 & 0 & 100 \\
$\mathbf{8 0}$ & 55 & 3 & 94,83 \\
$\mathbf{7 0}$ & 84 & 3 & 96,55 \\
& & & \\
\hline
\end{tabular}

Dari tabel diatas dapat dilihat bahwa pengujian mode percentage split menghasilkan akurasi tertinggi pada pengujian menggunakan split $90 \%$ yaitu dengan nilai akurasi yang akurat sebesar $100 \%$.

6. Hasil Evaluasi

Setelah melakukan beberapa mode pengujian dapat kita lihat rekapitulasi hasil akurasi yang dihasilkan untuk selanjutnya diambil kesimpulan, dengan rincian sebagai berikut :

Tabel 8. Hasil Evaluasi 4 mode pengujian

\begin{tabular}{cccc}
\hline Mode & Prediksi & Evaluasi & Akurasi \\
\hline Evaluasi & Benar & Salah & $\mathbf{( \% )}$ \\
Use training set & 279 & 10 & 96,54 \\
Supplied test set (Jan) & 20 & 2 & 90,91 \\
Supplied test set (Feb) & 17 & 1 & 94,44 \\
Supplied test set (Mar) & 13 & 0 & 100 \\
Cross-validation (k-3) & 280 & 9 & 96,89 \\
Cross-validation (k-6) & 280 & 9 & 96,89 \\
Cross-validation & 279 & 10 & 96,54 \\
(k-10) & & & \\
Percentage split (90\%) & 29 & 0 & 100 \\
Percentage split (80\%) & 55 & 3 & 94,8 \\
Percentage split (60\%) & 84 & 3 & 96,55 \\
Rata-rata & & & 96,36 \\
& & & \\
\hline
\end{tabular}

Dari tabel diatas dapat dilihat hasil evaluasi menggunakan 4 mode pengujian yang terdapat pada WEKA dengan menghasilkan nilai average sebesar $96.36 \%$.

\subsection{Perancangan sistem}

\section{Use Case Diagram}




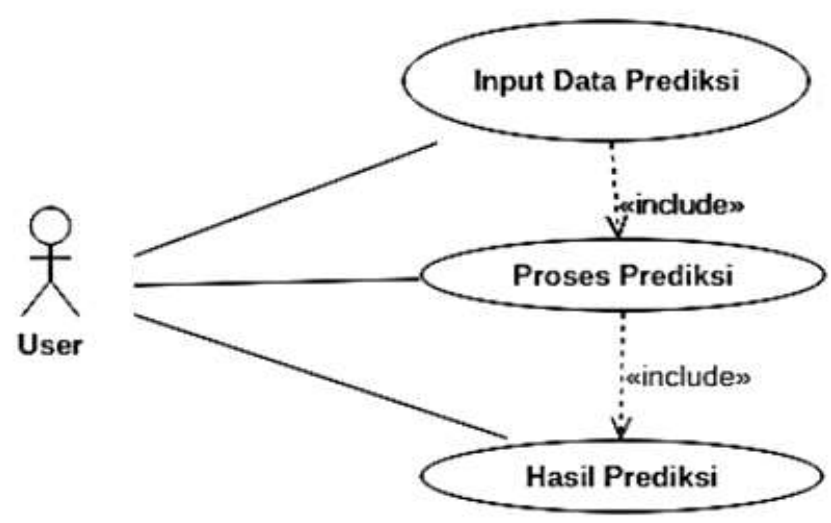

Gambar 6. Use Case Diagram User

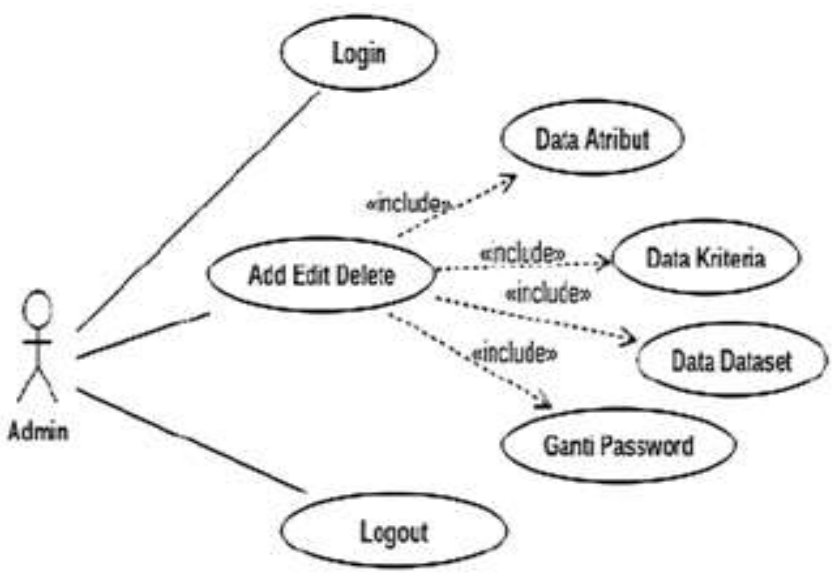

Gambar 7. Use Case Diagram admin

\section{Class Diagram}

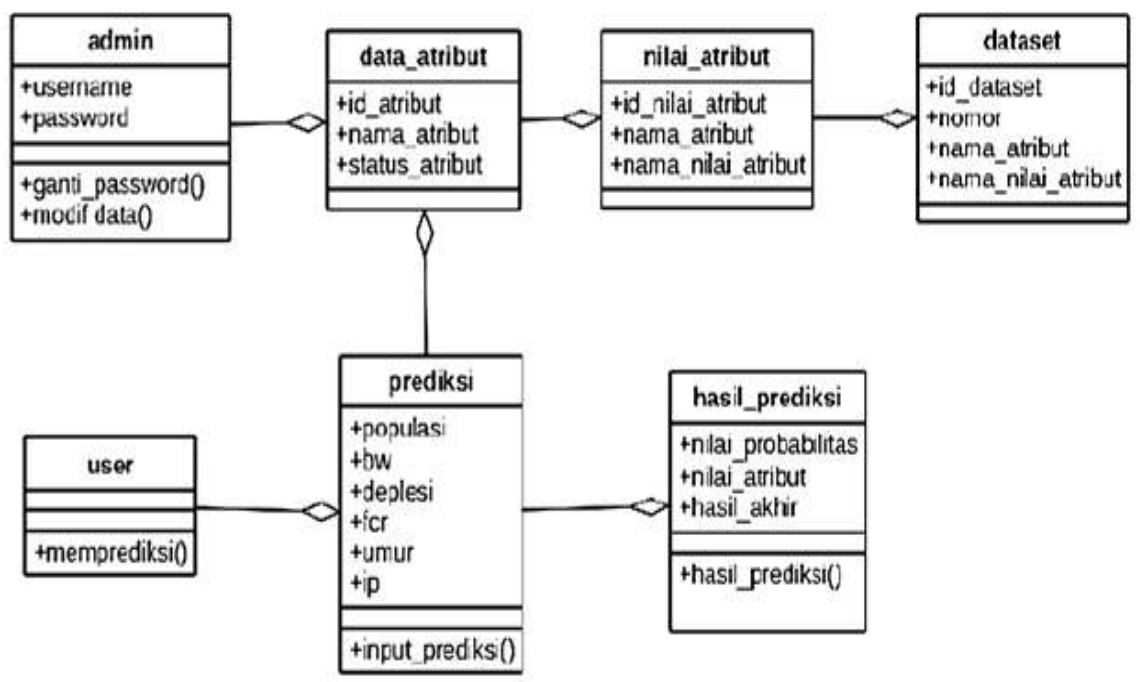

Gambar 8. Class Diagram yang dibuat 


\begin{tabular}{|c|c|c|}
\hline \multicolumn{3}{|c|}{ Sistem Pakar RHPP Netode Naive Bayes Classifier } \\
\hline \multicolumn{3}{|c|}{ 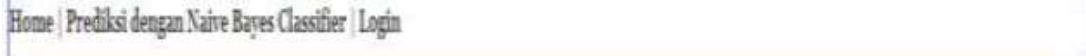 } \\
\hline & Selamat Datang & \\
\hline & - & \\
\hline 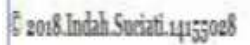 & & Fonth About \\
\hline
\end{tabular}

Gambar 9. Halaman Awal

Pada halaman awal aplikasi terdapat menu Home, Prediksi dengan Naive Bayes Classifier dan login. Menu login untuk masuk sebagai admin sedangkan untuk user dapat langsung menggunakan aplikasi ini dengan mudah tanpa harus login terlebih dahulu untuk melakukan prediksi untung rugi pada plasma dengan ouput hasil klasifikasi berikut dengan perhitungan nilai probabilitasnya.

Menu Prediksi Metode Naive Bayes Classifier digunakan untuk melakukan prediksi dengan menginput data training yang ingin diprediksi. Aplikasi akan menampilkan hasil prediksi menggunakan metode Naive Bayes berikut dengan proses perhitungannya untuk mengetahui nilai probabilitas terbesar yang kemudian dijadikan sebagai hasil prediksi.

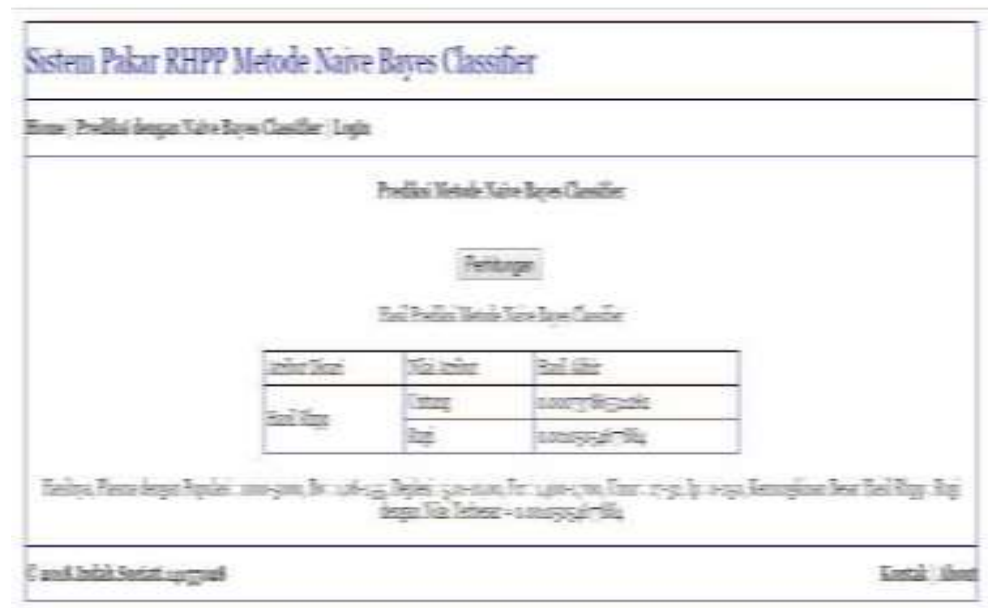

Gambar 10. Halaman Awal

Setelah menginput data training yang ingin diprediksi sesuai dengan data atribut yang telah ditampilkan. Kemudian pilih proses maka akan menampilkan kesimpulan hasil prediksi.

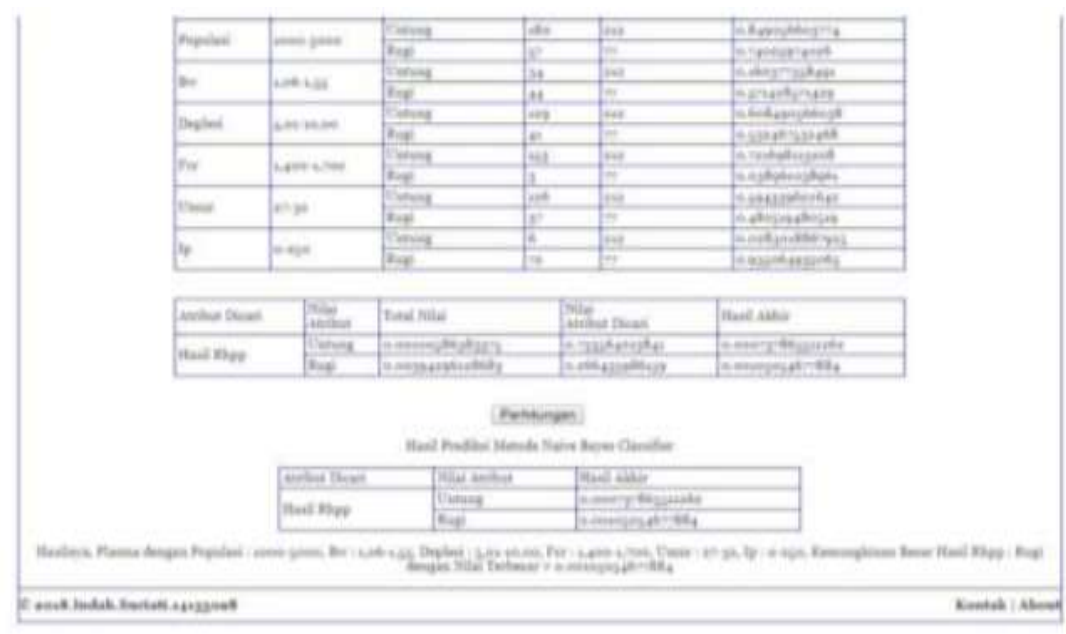

Gambar 11. Proses Perhitungan Hasil Prediksi 


\section{KESIMPULAN}

Penggunaan algoritma Naive Bayes mampu menghasilkan prediksi klasifikasi untung dan rugi sebelum dilakukan perhitungan realisasi pada bagian produksi. Sehingga, perusahaan maupun plasma dapat menjadikan acuan tersebut sebagai estimasi hasil akhir produksi dalam memonitoring performance plasma. Evaluasi pengujian algoritma Naive Bayes dari mode use training set menghasilkan nilai akurasi 96,54\%, dari mode supplied test set sebesar 95,12\%, dari mode cross-validation sebesar 96,77\%, dan dari mode percentage split menghasilkan 96,98\%. Tingkat akurasi rata-rata yang dihasilkan menggunakan algoritma Naive Bayes sebesar 96,36 \% mendekati angka 100\% menunjukkan bahwa model yang dihasilkan menunjukkan hasil yang maksimal. Dan dengan nilai ROC 0,9995 mendekati angka 1 maka model yang dihasilkan semakin baik. Sehingga dapat disimpulkan bahwa algoritma Naive Bayes merupakan algoritma klasifikasi yang direkomendasikan untuk melakukan prediksi klasifikasi untung rugi plasma. Uji aplikasi sistem yang telah dibuat menggunakan black box testing menghasilkan hasil valid dan tidak valid. Hasil tidak valid terjadi karena sistem masih menyimpan data input jika kosong namun hal ini tidak berpengaruh untuk hasil analisa prediksi. Sehingga dapat disimpulkan bahwa sistem yang telah dibuat mampu diimplementasikan sesuai dengan tujuannya yaitu melakukan analisa prediksi hasil produksi. Nilai black box testing sebesar $86,36 \%$ masih diatas nilai $70 \%$ sehingga menghasilkan sistem yang cukup baik.

\section{DAFTAR PUSTAKA}

[1] Santoso and Sudaryani, Panduan Praktis Pembesaran Ayam Pedaging, Penebar Swadaya, Jakarta Timur: 2015.

[2] Wahyul Hadi Saputro dan Moh, "Sistem Prediksi Untung Rugi Pada Hasil Peternakan Ayam Broiler Dengan Metode Klasifikasi Naive Bayes," Universitas Muhammadiyah Gresik, 2017.

[3] G. Karyono," Analisis Teknik Data Mining Algoritma C4.5 dan K-Nearest Neighbors Untuk Mendiagnosa Penyakit Diabetes Mellitus", Seminar Nasional Teknologi Informasi, Bisnis, dan Desain, STMIK - Politeknik PalComTech, 12 Mei 2016.

[4] N. Pratiwi dan Oktariani," Analisa Perbandingan Algoritma K-Means,Decision Tree dan Naive Bayes Untuk Sistem Pengelompokkan Siswa Otomatis”, Jurnal Ilmiah Teknologi Informasi Terapan, Volume II, No 2, 15 April 2016.

[5] Hananto, V. Roby," Analisis Penentuan Metode Data Mining Untuk Prediksi Kelulusan Mahasiswa Sebagai Penunjang Angka Efisiensi Edukasi”, Jurnal Ilmiah SCROLL, 5 (1). pp. 1-11. ISSN 2338-8625.

[6] N. Abdulrahman and W. Abedalkhader," Classifier and Nä̈ve Bayes Classifier For Crime Prediction in San Fransisco Context”, International Journal of Database Management Systems ( IJDMS ) Vol.9, No.4, August 2017.

[7] Tamalludin, Ferry. E-book: Panduan Lengkap Ayam Broiler. Jakarta : PT. Penebar Swadaya, 2014.

[8] R. Fadilah,. E-book: Beternak Ayam Broiler. Jakarta : PT. AgroMedia Pustaka, 2013.

[9] R. Fadilah. E-book : Super Lengkap Beternak Ayam Broiler. Jakarta : PT. AgroMedia Pustaka, 2013. 52.

[10] MaxiGrow Indonesia. (May 22, 2018). Indikator-Keberhasilan-Peternakan Broiler (Koran online], Available: http://www.maxigrowindonesia.com/indikator-keberhasilan-peternakanbroiler/

[11] R. Rosnelly,. E-book: Sistem Pakar, Konsep dan Teori. Yogyakarta : Andi, 2012.

[12] Kusrini dan E. T. Luthfi. E-book: "Algoritma Data Mining”. Yogyakarta: Andi, 2009.

[13] D. Nofriansyah,. E-book : "Konsep Data Mining vs Sistem Pendukung Keputusan”. Yogyakarta : Deepublish, 2014. 